\title{
Protection of collective rights and interests in arbitration
}

\author{
Vladimir Veniaminovich Dolganichev ${ }^{*}$ and Svetlana Pavlovna Grubtsova \\ Ural State Law University, Department of Civil Procedure, Ekaterinburg, Russia
}

\begin{abstract}
Objective of the research: to identify the means of protection of collective interests, suitable for international commercial arbitration, based on models used in Russian procedural law and abroad. The research used both general scientific (analysis, synthesis, comparison, descriptive, formal-logical) and special legal (formal-legal, comparative-legal, historical-legal, method of legal modeling) methods. The work has resulted in a conclusion about the expansion of the use of collective rights and interests' remedies in international commercial arbitration. In addition, conclusions are formulated on the admissibility in arbitration of such means of protection of collective rights and interests of procedural law as complicity, class actions, bankruptcy, protection of an indefinite range of persons and indirect claims. In particular, such a classic remedy of multiple persons as procedural complicity is often used in arbitration; on the other hand, rules are emerging on the possibility of using a class action to protect multiple persons in arbitration; the use of an indirect claim is also not restricted to arbitration, and it can be used subject to national law. The novelty of the research lies in the postulate of the impossibility in the modern legal process of using the institute of protection of an indefinite range of persons in arbitration due to the special nature of arbitration as a voluntary form of protection of rights and legitimate interests.
\end{abstract}

Keywords: collective interest, remedies, arbitration, civil procedure, class actions

\section{Introduction}

The participants in the legal relations from which a dispute requiring resolution may arise may be a large number of persons. In today's world, the procedural system cannot exist solely in the context of resolving the claims of a single plaintiff against a single defendant [1].

In this regard, many modern jurisdictions have created procedural means of protecting collective interests: protection of an indefinite range of persons, optional complicity on the side of the plaintiff, class actions, indirect (derivative) suits, insolvency (bankruptcy).

However, these procedural institutions are actively developing within national procedural and judicial systems. At the same time, an alternative method of resolving legal disputes - international commercial arbitration attracts more and more attention and

* Corresponding author: dolganichev@mail.ru 
continues to be evaluated by most specialists as having its own undeniable advantages [25].

In connection with the above, the question of the use of means of protection of collective interests in arbitration proceedings becomes relevant and interesting. It should be noted that the research of issues of separate institutes of protection of collective interests and arbitration (arbitration proceedings) in Russian and foreign literature is given sufficient attention. In turn, the problems of protection of collective interests in arbitration on the basis of procedural constructions related to the plurality of persons have not been considered.

In this paper, the authors justify that the collective remedies existing in the civil procedure for the protection of rights and legitimate interests are applicable to the consideration of cases in international commercial arbitration. The purpose of the study is to identify the means of protection of collective rights and interests in arbitration based on models used in the Russian procedural legislation and abroad. It is achieved by solving the problems of studying such means in the civil procedure and arbitration, and analyzing their interrelation and specificity.

\section{Methods}

Within the framework of the present research, we used both general scientific (analysis, synthesis, comparison, descriptive, formal-logical) and special legal methods (formal-legal, comparative-legal, historical-legal, method of legal modeling).

\section{Results}

At the level of the procedural legislation of Russia, subjects are given ample opportunities for the protection of rights and interests in a plurality of persons in a particular legal relationship from which the dispute arose.

A) The institute of complicity. Procedural complicity means the simultaneous participation of several persons on the side of the plaintiff and/or defendant - cocomplainants and co-defendants [6].

B) Protection of an indefinite range of persons. The introduction into Russian procedural law of rules on the protection of the interests of an indefinite group of persons, the composition of which cannot be personalized at the time of the institution of the case in court, was in its time an important step towards the development in the future of the institute of class action.

These statutory constructions can be called classic for the civil procedure. Relatively new procedural means of collective protection are:

A) Class actions. Through the class action construction, collective interests as well as the rights of specific participants in large groups of persons [7] are protected. A class action is generally understood as a procedural mechanism that allows plaintiffs to sue not only on their own behalf, but also on behalf of others with the same interests [8].

A class action has a number of advantages over the above means of collective protection, among which stand out: greater accessibility of justice, reduction of financial and time costs of the court and parties [9]. Obviously, there are some disadvantages [10].

B) Indirect (derivative) claims. Indirect claim, as well as class action, is a new form of protection for the Russian system, which is a claim aimed at protecting the rights and legitimate interests of a person who is not a party to a material legal relationship. A classic example of an indirect claim is a claim against a director for recovery of losses in favor of a legal entity brought by its participant [9]. 
C) Insolvency (bankruptcy). This institution has many conceptual similarities with group proceedings: the community of creditors gets the protection of their interests through the actions of a bankruptcy trustee, who puts the issues related to the formation, protection, distribution of the bankruptcy estate on the court's decision in the interests of such a community. In those disputes where the law gives the bankruptcy trustee the exclusive right to act on behalf of the community of creditors and the debtor, creditors and the debtor have no right to dispose of the remedy to protect their interests, highlighting the commonality of a bankruptcy case with a class proceeding $[8,11]$.

Foreign doctrine and procedural legislation in this regard take a broader approach to the solution of the issue of procedural tools for the protection of collective rights and interests. Thus, the US legislation knows the category of "complex, or aggregate, litigation", including both class actions and torts involving a large number of persons (mass torts), cases assigned for centralized management, litigation in several districts (multidistrict litigation) [12].

\section{Discussion}

Turning to arbitration, we note that the question of the protection of collective rights and interests is here predetermined by the widespread multiplicity of persons involved in an international commercial contract, in connection with the conclusion and violation of which there is a dispute to be resolved. Gary Born, in the context of multi-party issues, points to the institutions of (a) consolidation, (b) joinder, and (c) intervention [13]. We believe that the abovementioned grounds should be considered as complicating circumstances of arbitration, transforming it into multi-party arbitration.

Taking into account that the regulation of arbitration issues may be carried out comprehensively both at the level of individual national jurisdictions and at the level of various arbitration rules. The examples of the use of appropriate constructions conditioned by the plurality of persons may be the provisions of the International Court of Arbitration Rules at the International Chamber of Commerce (ICC).

Thus, on January 1, 2021 entered into force changes to the Arbitration Rules of the International Court of Arbitration at the International Chamber of Commerce (ICC) [14], in particular aimed at solving problems in complex multilateral proceedings in arbitration. Now the procedure of joining the arbitration by new participants (joinder of additional parties) does not require, as before, the consent of all parties to the dispute. And the consolidation of several arbitrations (consolidation of arbitrations) under these rules is also possible if the grounds for the competence of arbitration in such processes are different arbitration agreements [15].

The literature also points to the use in international commercial arbitration of a form of collective redress [16] as a class arbitration, which allows one or more parties to submit a claim to arbitration on behalf of others similarly situated to them [17].

From the above, we conclude about the admissibility of application in arbitration of the procedural constructions of complicity and class action. At the same time, taking into account the consensual, autonomous and voluntary basis and the legal nature of this method of settlement of legal disputes, today there are no opportunities for protection of an indefinite number of persons in international commercial arbitration.

The possibility of indirect claims (shareholder suits) in arbitration is confirmed by foreign experience. Thus, the most advanced in this respect is Germany, where under conditions of arbitrability of corporate disputes, shareholders in arbitration are provided with means of collective protection of their rights [16]. This model of protection of shareholders' rights in Germany is set forth in the Supplementary Regulation on Corporate 
Disputes (the DIS Supplementary Rules for Corporate Law Disputes), established by the German Institution of Arbitration).

Due to the exclusive competence of national courts with regard to insolvency (bankruptcy) cases, only isolated disputes in insolvency (bankruptcy) cases can be discussed in the field of arbitration proceedings [18].

\section{Conclusion}

As a result of the research, we can conclude that in international commercial arbitration the following means of protection of collective rights and interests are allowed such as participation, class actions, indirect claims and bankruptcy. The models analyzed in arbitration correlate with the constructions of procedural law, designed to solve the problems of litigation when a dispute is complicated by a plurality of persons. A promising direction in the development of the institute of arbitration proceedings is to expand the means of protecting collective rights and interests including in bankruptcy, recognizing arbitration disputes on the participation of multiple persons on the creditor side, as well as providing new opportunities for indirect claims.

\section{References}

1. A.R. Miller, Theoret. Inquir. Law 19(1), 1-45 (2018). https://doi.org/10.1515/til-20180001

2. S.N. Lebedev, Mezhdunarodnoe sotrudnichestvo v oblasti kommercheskogo arbitrazha [International cooperation in the field of commercial arbitration] (Torg.-prom.

Publishing house, Moscow, 1979)

3. O.Y. Skvortsov, Treteiskoe razbiratelstvo predprinimatelskikh sporov v Rossii: Problemy. Tendentsii. Perspektivy [Arbitration proceedings of entrepreneurial disputes in Russia: Problems. Trends. Prospects] (WoltersClover, Moscow, 2005)

4. E.I. Nosyreva, Alternativnoe razreshenie sporov v SShA [Alternative Dispute Resolution in the USA] (Gorodets, Moscow, 2005)

5. S.A. Kurochkin, Treteiskoe razbiratelstvo i mezhdunarodnyi kommercheskii arbitrazh [Arbitration proceedings and international commercial arbitration] (Statute, Moscow, 2017)

6. O.S. Goncharova, Souchastie v grazhdanskom protsesse Rossii i SShA [Complicity in Civil Proceedings in Russia and the USA] (Prospect, Moscow, 2014)

7. Federal Rules of Civil Procedure. Rule 23. Class Actions. Accessed on: June 27, 2021. [Online]. Available: https://www.law.cornell.edu/rules/frcp/rule_23

8. R.H. Klonoff, Class Actions and Other Multi-Party Litigation in a Nutshell (West Academic Publishing, 2017)

9. V.V. Yarkov, V.V. Dolganichev, Prosp. Sci. Edu. 6, 141-142 (2020). https://doi.org/10.32744/pse.2020.6.11

10. N.A. Sutormin, State and Law, 7, 119-123 (2020). DOI: $10.31857 /$ S102694520010712-4

11. I.M. Shevchenko, Zakon, 2, 71-82 (2021).

12. B.R. Martinotti, Loyola Univ. Chicago Law J. 44(2), 561-576 (2012)

13. G. Born, International commercial arbitration (Klumer Law International B.V., the Netherlands, 2020) 
14. The ICC Arbitration Rules. Accessed on: June 27, 2021. [Online]. Available: https://iccwbo.org/dispute-resolution-services/arbitration/rules-of-arbitration/

15. The ICC Arbitration Rules. Article 10. Accessed on: June 27, 2021. [Online]. Available: https://iccwbo.org/dispute-resolution-services/arbitration/rules-ofarbitration/\#article_10

16. S.I. Strong, Univ. Missouri Sch. Law Legal Stud. Research Paper, 2019-09 (2019)

17. F. Blavi, G. Vial, Fordham Internat. Law J. 39(4), 2, 793-795 (2016)

18. Y.D. Podolsky, Obosoblennye spory v bankrotstve [Separate disputes in bankruptcy] (Statute, Moscow, 2020) 